Barkasi D.

\title{
Effective tools for integrating social service recipients into the community
}

\author{
St. Elizabeth college of health and social work, Michalovce, Slovakia
}

daniela.barkasi@gmail.com

\section{Introduction}

The main starting point for the transition from institutional to community care in the social services system is the introduction of the principles of independent living. Changes in the system of providing social services and the transition from institutional to community care in the Slovak Republic require the application of effective tools for the integration of social service recipients into the community environment. The aim of the presented paper is to point out the importance of individual planning and social rehabilitation in increasing the status of recipients in social service facilities.

Social service recipients with mental disabilities need constant help and assistance in carrying out day-to-day activities. The placement of such a person in social service facilities is often understood in the general public as the final or definitive solution to a given problem and no further intervention and development is needed. However, people with mental disabilities are full citizens of society and have the right to respect for human rights [1]. They have the right to choose quality social services that support their independence and independent living as much as possible. Independent living can be achieved if social services are available in the community according to their individual needs and the needs of their families with the support and protection they need. To ensure that community-based services are provided on an individual basis, people with disabilities must be involved in their development, along with other key people and institutions. The network of support services must be based on individual needs and the services must correspond to the aspirations, goals, plans and possibilities of the person with a mental disability. The process of deinstitutionalisation of social services enables them and provides them with the opportunity to fully integrate into the community of the city or municipality. Its aim is to create and ensure conditions for the independent and free life of all citizens who depend on the help of society in the natural social environment of the community. Deinstitutionalisation enables these people to live free and independent way of life with the support of the community and effective tools for integrating social service recipients.

Basic human rights documents. The process of deinstitutionalisation of social services itself stems from many international documents, pacts and conventions, where the Slovak Republic is one of the parties involved. These are the Universal Declaration of Human Rights, the International Covenant on Civil and Political Rights [2], where Art. 9 declares the right of a person to freedom and personal security, at the same time regulates the procedure for restricting a person's personal freedom, in Art. 17 states a person's right to protection against interference with the private life of the person, his family, home or documents. Furthermore, the International Covenant on Economic, Social and Cultural Rights [3], where in Art. 11 the Contracting Parties to the Covenant recognize the right of a man to an adequate standard of living, and in Art. 12 we find the right of everyone to achieve the highest attainable level of physical and mental health with a view to improving the situation in all aspects of a possible disease. Convention on the Rights of the Child [4], where in Art. 22 we find information that in meeting the needs of the child, care in the family environment complements and overlaps with residential care, even if there are residential facilities with a large capacity, it is necessary to approach their gradual deinstitutionalization and gradually eliminate these facilities.

Changes in the system of providing social services in the Slovak Republic. According to Act no. 448/2008 Coll. [5] on social services, social services are defined as professional activity, service activity or other activity or set of these activities, which are aimed at prevention of unfavorable social situation, solution of unfavorable social situation or alleviation of unfavorable social situation of natural person, family or community, preservation, renewal or development of natural person's ability to lead an independent life and to support his integration into society, ensuring the necessary conditions to meet the basic living needs of a natural person, solving the social emergency situation of a natural person and family, preventing social exclusion of a natural person and family, providing child care due to the family situation that requires help in taking care of a child.

National documents for the transition from institutional to community care. The basic documents of the transition from institutional care to community care at the national level include in particular the National Priorities for the Development of Social Services in Slovakia, as well as the Strategy for Deinstitutionalisation of Social Services and Substitute Care in the Slovak Republic and the resulting National Action Plans for Deinstitutionalisation.

National priorities for the development of social services in Slovakia in 2015-2020. National priorities for the development of social services are developed in accordance with the competence of the Ministry of Labor and Social Affairs, with Act no. 448/2008 Coll. [5] on social services as a 
tool of state policy for the development of social services and are also a systemic expression of the interests, tasks and support measures of the Government of the Slovak Republic in this area. They are a response to the modernization of social services. However, they also confirm the main mission of these services, which are social cohesion, their transformation and the obvious employment potential. They reflect the real situation of social service provision in the Slovak Republic (ie especially their unavailability and insufficient material and technical and personnel conditions for the provision of social services), and are based on needs identified within the Slovak Republic and European Community priorities (availability and accessibility of social services and their financial sustainability). The main goal of the National Priorities is to positively influence the development of social services in the Slovak Republic in 2015-2020 by formulating the basic priorities of this development, the preconditions for achieving these priorities and measurable indicators for assessing their fulfillment. In relation to the main goal of the National Priorities, the Ministry of Labor, Social Affairs and Family also defined specific goals (MLSA SR, 2014):

- to ensure the realization of the citizen's right to the provision of social services, taking into account the human rights and non-discriminatory approach and the emphasis on respect for human dignity,

- ensure the availability of social services in accordance with the needs of target groups and communities, ensure the development of social services available to people in segregated localities with the presence of concentrated and generationally reproduced poverty,

- increase the availability of community social services with an emphasis on the development of social services for a family that takes care of its member, who depends on the help of another person in self-service,

- not institutionalize social services,

- promote the principle of integrated long-term health and social care,

- introduce a system of ensuring and evaluating the conditions of quality of provided social services.

It is important to emphasize the priority of deinstitutionalisation, and in the case of the national document defined above, the priority is to support the transition of social service recipients from institutional care to community care. This priority specifically concerns ensuring the continuity and effectiveness of the social services provided in an effort to support the retention of individuals in their natural family environment. It aims to create conditions for the independent life of the young and adults with disabilities and mental disorders.

Strategy of deinstitutionalisation of social services and alternative care in the Slovak Republic. According to some actors of social work, the deinstitutionalisation strategy not only fills a gap in the program structure of the conceptual direction of social services and alternative care in Slovakia, but also sets a clear intention and program line for making the necessary changes that would lead to achieving deinstitutionalisation goals.
The strategies are:

- evaluation and revision of the Strategy for the deinstitutionalisation of the system of social services and alternative care in the Slovak Republic,

- evaluation and revision of the tasks of the National Action Plan for the Transition from Institutional to Community Care for 2011-2015 and specification of the tasks for 20162020.

The 6 measures proposed under this Strategy concern:

- Creation of legal conditions to support deinstitutionalisation in social services (radical amendment to Act No. 448/2008 Coll., On social services of 28 November 2013, No. 485/2013 Coll., Which introduced several changes supporting the deinstitutionalisation process).

- Preparations for the National Action Plan for the Transition from Institutional to Community Care in the Social Services System for 2011-2015 (later 2016-2020).

- Reassessment of the current Concept of Ensuring the Enforcement of Judicial Decisions and updating the Concept of Ensuring the Enforcement of Judicial Decisions for 20112015 with a view to 2020 (plan for the transformation and deinstitutionalisation of institutional care in children's homes).

- Preparation of the National Project to Support the Deinstitutionalisation of Care Services.

- Preparation of the National Project to Support the Deinstitutionalisation of Substitute Care.

- Establishment of the Committee of Experts for Deinstitutionalisation (the original plan to create a National Center for the Support of Deinstitutionalisation, but this task was taken over by the Implementing Agency of the Ministry of Labor, Social Affairs and Family of the Slovak Republic).

Deinstitutionalisation - the trend of social services development. The primary goal of deinstitutionalisation is to create conditions for the social service recipient to live freely and independently with the support of the community, professionals, family members, volunteers by moving from a predominantly institutional way of providing social services to community care. According to Vansač [6], the community is a common experience of people, which has external and internal features on two levels, as social ties between members within the community and the wider social environment.

The deinstitutionalisation process is of a strategic nature for social services. Krúpa (2008) defines this process as a process that transforms a system originally focused on the care of people with disabilities excluded from society into a system that should ensure the integration of these people into society, by providing such a portfolio of services at the community level that respects its basic needs. It is in the National Action Plan for the Transition from Institutional to Community Care in the System of Social Services for 2016-2020 that it is possible to see a very concise description of what exactly the process of deinstitutionalisation should ensure.

This is to remove:

- rigid and stereotypical and routine activities - in terms of a fixed time and structure of activities, disrespect for personal needs and interests, 
- flat-rate treatment procedures so that recipients of social services are not treated en masse, without respecting their privacy and individuality,

- social distance and paternalism, which represent a different position of staff and clients, an unbalanced relationship of power,

segregation from the local community - eccentric location of social service facilities, distance from the local community and concentration of services at one place,

- learned passivity - acquired passive behavior of people and their helplessness and underdeveloped social relationships.

Deinstitutionalisation presupposes the transformation of the original model of institutionally oriented large-scale residential facilities and the creation and development of a network of such community services that will support the integrity and inclusion of the inhabitants of the given community or society.

Holúbková [7] states that:

- deinstitutionalisation is a social process of gradual change from institutional care and segregation to independent living and a community where support services are also provided,

recipients of social services leave social service homes and segregated residential facilities after targeted training, while the provision of individualized social services in the community is supported so that they are of a sufficient quality level,

- social services are intended not only for those who previously lived in a residential social service facility, but also for those who did not have such assistance available in their place of residence, but are entitled to them due to their condition and difficulties,

- users of social services are entitled to housing in the community and also access to public services, as well as to personal assistance - if the necessary conditions are met.

Holúbková [7] also talks about the preventive effect of deinstitutionalisation, as it prevents a return to the original models of institutional care. Based on the above facts, it is necessary to define the principles that lead to the success of this great, ambitious and especially necessary change in the way of caring for people dependent on social services in Slovakia, especially the adoption of this way of implementing social services by the general public, changes in people's thinking and cooperation of all stakeholders in the first instance.

Effective tools for involving community beneficiaries. We focused above on the basic principles of deinstitutionalisation, as a necessary process in the transition from institutional to community care. This process is conditioned by the implementation of other tools to support the implementation of the above, such as individual planning in social services and social rehabilitation.

Human resources as the highest value for the transition from the institution to the community. The process of transition from institutional to community care in the social service system is a demanding and long-term process requiring uniform coordination and management of all stakeholders. When managing the process of change in the social service system, it is necessary to pay systematic attention to the coordination of key partners at both the national, regional and local levels. At the national level, it is a matter of content and time coordination of the National Project of Support for the Deinstitutionalisation of the Social Services System and also coordination of individual investment pilot projects implemented by social service providers in selected social service facilities and coordination of the preparation of necessary legislative changes. At the regional or local level, it is the implementation of investment preparation of community services, through the preparation and development of human resources for these services.

In this process, self-governing regions have important coordination roles in relation to staff and recipients of social services in facilities, but they also are and will be responsible for the comprehensive construction of community services in selected localities. Throughout the process, mechanisms are and will be introduced for respecting the rights of social service recipients and for their involvement in this process (MoLSAEO SR, 2016).

During the actual implementation of transformation processes in specific social service facilities, the functional structures of employees are ensured, i. transformation teams (director of a social service facility, deputy director, managers, economist, social worker, therapists, psychologist, representative of social service recipients). Unlike a hierarchical way of collaborating (where processes are managed by only one supervisor), a team of people work together to find ways to achieve transformation. Teamwork is essential. It is also very positive that the representatives of the social service recipients are also members of these transformation teams [8].

Individual planning in social services. The term individual plan means an agreement between the user of the social service and the service, where the personal goals and real wishes of the client are set. The goals stem from the needs and wishes of the client, they are realistic, quantifiable, their achievement is within the possibilities of social service and the recipient must make some effort to meet them.

In the context of the principles of individual planning, it is important to follow the provisions of Act no. 448/2008 Coll. on social services, which introduced the obligation of the social service provider to meet the quality conditions of the provided social service, which in detail sets out the criteria, standards and indicators of quality of the provided social service divided into four areas (respect for basic human rights and freedoms, procedural conditions, personnel conditions, operating conditions).

Within the procedural conditions that give obligations in the field of respect for the fundamental rights and freedoms of social service recipients, a specific criterion entitled Determination of procedures and rules for elaboration, implementation and evaluation of individual social service recipient plan or determination of procedures and rules of work with social service recipients we can see the described and defined standard dealing with individual planning in the system of social services. Repková [9] characterizes individual planning as a method aimed at applying the participation of the 
social service recipient in deciding how the social service will be set (in terms of its organizational aspects), provided (in terms of procedures, methods and techniques used) and evaluated (for reflecting on changes in the needs of the recipient of the potential change). Individual planning includes the identification of individual needs, the choice of the goals of the individual plan, the methods of achieving the goals, the plan of actions and activities to fulfill the individual plan and finally its evaluation.

Chovanec [10] states that on the basis of how individual planning is characterized and on the basis of what it involves, it is possible to define very clearly its benefits:

- the recipient of the social service can be considered as an equal partner,

- its health and mental condition, individual needs, habits, personal goals and current possibilities are taken into account,

decision-making powers of the social service recipient as well as the choice of available support and assistance options,

- respect for his fundamental human rights,

- a sense of security, as based on planning, there is an agreement between the recipient and the social service provider on how, with whom and for what period of time the service will take place.

The planning process of individual planning begins with the fact that the social service recipient is, based on his personal preference, designated a key worker who will accompany and support him in this process. The relationship between the social service recipient and the key worker is extremely important.

The author Johnová [11] divides the very phases of individual planning as follows:

- Identification of individual needs, where it is necessary to prepare a personal profile and analyze the degree of necessary support (needs) of the person.

- Target selection focuses on selecting targets in the areas that have been identified in the mapping. The goals of an individual plan are based on the individual needs of the user and his family. The stated goal should be clearly aimed at cooperation between the supported person and the people who provide this support.

Selection and description of methods - methods, procedures and techniques for achieving selected goals are determined. We distinguish between methods that are developmental in nature and methods that aim to maintain or increase the quality for people with high level of support.

- Action plan - contains, in a simplified form, answers to the questions: Who? - definition of members of the work team who will participate in the activity together with the client. What? - definition of the activity that the client will engage in. When? - forms a time schedule for skills training. How? - the way in which those activities will be implemented in practice. Where? - the context in which the training will take place. With what? - provides basic information on the necessary tools that must be used if necessary

Evaluation - should take place at regular intervals and thus allows continuous evaluation of success or failure of the individual planning process itself but also of the chosen method.

Social rehabilitation as a tool for the recipient's independence. Social rehabilitation is in Act no. 448/2008 Coll. on social services defined as a professional activity to support the self-reliance, independence and self-sufficiency of a natural person by developing and practicing skills or activating skills and strengthening habits in self-service, household care and basic social activities with maximum use of natural resources in the family and community. In the case of a person's dependence on the help of another natural person, social rehabilitation represents mainly training in the use of aids, training in housework, training in spatial orientation and independent movement, teaching Braille writing and reading and social communication, but also strengthening cognitive and memory skills [12].

According to Hirčková [13], social rehabilitation is a set of different activities needed to practice the skills necessary for the normal functioning of a person with a health or other disability in society. Social rehabilitation has a wide scope and is connected with everything that a person with a disability needs to integrate into everyday life.

Based on the definitions of social rehabilitation, it is also possible to define its objective and especially achievable goals:

- self-sufficiency and development of people with disabilities and their return to the natural environment,

- renewal, resp. lifestyle acquisition,

- developing the skills of social service recipients,

- reduction of social risks such as loneliness, inability

to adapt due to stereotypical leadership in social service facilities, etc.,

- preventing and improving the deterioration of health or mental health,

- provision of educational and activating means,

- promoting and maintaining social ties with family and friends, supporting people with disabilities in finding employment and learning how to manage money,

- promoting the meaningfulness of leisure time,

- encouraging them to be independent.

As for the forms of social rehabilitation, they are not directly affected by the legislation, but especially by the needs of the social rehabilitation recipients. They depend on their health and mental condition, problems, their age and abilities.

Hirčková [13] defines the following forms of social rehabilitation in her works:

- Therapeutic - this includes treatment and medical procedures to achieve a state of relative health.

- Educational and pedagogical rehabilitation - it is focused on education, upbringing and preparation for life.

- Employment and occupational rehabilitation - is aimed at including a person with a disability in the work process, so that they can perform this task independently within their capabilities. In practice, this means acquiring the work skills they will need to do the job.

- Psychological rehabilitation - its goal is to manage stressful situations that arise in connection with the life of the person with disability. 
- Leisure rehabilitation - is a very suitable way to support the independence of any disabled person. People with disabilities can meet new people with similar difficulties as part of various leisure rehabilitation events.

\section{Conclusions}

Every person with any disability who depends on social care can live, learn, work, live, perform suitable leisure activities and relax as he imagines, as much as the context of his disability allows him to. The Slovak Republic is really actively responding to the changing situation in Europe regarding social issues, which can be seen at the changing legislation to the coordination of various activities at the regional level. The quality and level of social services in the Slovak Republic represents the state and self-government. The maturity of society is also measured by how it takes care of the weakest. The deinstitutionalisation of social service facilities leads to a certain extent to an increase in the quality of social service provision.

\section{References}

1. Popovičová, M. Semeš. M. 2019. Sociálna práca v kontexte etických princípov. In: Schavel, M., Gállová, A. (eds.). Zborník vedeckých medzinárodných príspevkov Trendy a inovácie vo vysokoškolskom vzdelávaní v odbore sociálna práca. VSZaSP sv. Alžbety Bratislava 2019, s. 261-272. ISBM 978-80-8132-202-0.

2. Medzinárodný pakt o občianskych a politických právach. [online]. [cit. 24.08.2020]. Dostupné na internete: https://www.amnesty.sk/wp-content/uploads/2012/01/Medzin\%C3\%A1rodn\%C3\%BD-pakt-o-ob\%C4\%8Dianskych-a-politick $\%$ C3\%BDch-pr\%C3\%A1vach.pdf.

3. Medzinárodný pakt o hospodárskych, sociálnych a kultúrnych právach. [online]. [cit. 22.08.2020]. Dostupné na internete: https:/www.amnesty.sk/wp-content/uploads/2012/01/Medzin\%C3\%A1rodn\%C3\%BD-pakt-ohospod\%C3\%A1 rskych-soci\%C3\%A1lnych-a kult\%C3\%BArnychpr\%C3\%A1vach.pdf.

4. Dohovor o právach diet'at'a. [online]. [cit. 03.08.2020]. Dostupné na internete: https://www.amnesty.sk/wp-content/ uploads/2012/01/Dohovor-o-pr\%C3\%A1vach die\%C5\%A5a\%C5\%A5a.pdf.

5. Zákon $\mathrm{Nr} \mathrm{Sr}$ č. 448/2008 Z. z. o sociálnych službách a o zmene a doplnení zákona č. 455/1991 Zb. o živnostenskom podnikaní (živnostenský zákon) v znení neskorších predpisov.

6. Vansač, P. 2020. Sociálne služby. VSZaSP sv. Alžbety, n.o. v Bratislave, Detašované pracovisko bl. Metoda Dominika Trčku, Michalovce. PrintMedia Michalovce. ISBN: 978-80-8132-215-0. 124 s.

7. Holúbková, S. 2013. Odvaha na nové sociálne služby. [online]. [cit.20.8.2020]. Dostupné na internete: http://www.iness.sk/sites/default/files/media/file/pdf/INESS_Odvaha_na_nove_sluzby.pdf.

8. Brichtová, L. a kol. 2015. Riadenie a manažment prechodu z inštitucionálnej na komunitnú starostlivost'. Bratislava : Implementačná agentúra Ministerstva práce, sociálnych vecí a rodiny Slovenskej republiky. 2015.101 s. ISBN: 978-80-970110-7-9.

9. Repková, K. 2015. Implementácia podmienok kvality do praxe poskytovatel'ov sociálnych služieb - metodické východiská. Bratislava. Inštitút pre výskum práce a rodiny, 2015. [online]. [cit. 22.08.2020]. Dostupné na internete: https://www.employment.gov.sk/files/slovensky/rodina-socialna-pomoc/socialne-sluzby/metodika-verzia-3.12-komplet.pdf.

10. Chovanec, J. a kol. 2013. Individuálne plánovanie a individuálny plán v sociálnych službách. Bratislava: Vysoká škola zdravotníctva asociálnej práce sv. Alžbety,2013. 174 s. ISBN 978-80-8132-091-0.

11. Johnová, M. 2007. Transformácia domovov sociálnych služieb s ciel'om sociálnej a pracovnej integrácie ich obyvatel'ov. Bratislava: Rada pre poradenstvo v sociálnej práci. [online]. [cit.21.08.2020]. Dostupné na internete: http://www.rpsp.sk/download/transformacia_dss.pdf.

12. Belovičová, M., Vansač, P. 2019. Selected aspects of medical and social care for long-term ill persons. Towarzystwo Slowakow w Polsce. Krakow 2019, 153 s. ISBN: 978-83-8111-109-6.

13. Hirčková, M. 2008. Sociálna rehabilitácia ako nástroj podpory nezávislosti l’udí so zdravotným postihnutím. [online]. [cit. 02.08.2020]. Dostupné na internete:http://www.nrozp.sk/files/NROZP_vzostupna_opt.pdf.

Дата надходження рукопису до редакції: 25.08.2020 p.

\section{Відомості про автора}

Assoc. Prof. Daniela Barkasi, RNDr. Mgr. PhD. - St. Elizabeth College of Health and Social Work, Detached workplace bl. Metoda Dominika Trčku, Partizánska 23, Michalovce 07101, Slovak Republic.

+421905193126, daniela.barkasi@gmail.com. 